\title{
Case Study: The Management of Risks to Employees and Consumers of the Catering Industry in the United Kingdom and France*
}

\author{
by Alan Gordon
}

\section{Introduction}

The concept for this study was based on the Consultex proposal of December 1990 which proposed to the Geneva Association that an analysis be made of the catering / food service market from the standpoint of employee and public liability risks in the UK and France. The new Food Safety Act in the UK which came into force in 1991 has been a watershed event.

Eating outside the home, whether in institutional, office/factory or commercial catering establishments is a vast and increasing business. It involves the preparation and serving of millions of meals per day and the spend on meals outside the home (not counting drinks) is about $40 \%$ of the total amount spent in purchasing food in retail stores for home consumption. In America, as the American housewife has essentially stopped cooking, purchases of meals outside the home, including take out meals, is now larger than the retail food spend.

Two detailed country reports were produced for the UK and France which showed the structure and size of the catering market, the main economic agents, the food hygiene stipulations and enforcement procedures, the main employee and public claims related to the catering business and case histories of large catering groups.

\section{Main features of UK catering market}

\subsection{General overview}

There are approximately 270,000 establishments in the UK which cater to consumers outside the home by providing cooked meals and snacks. These establishments served approximately 7 billion meals in 1989 , made food purchases of $£ 5.3$ billion and the meal output value at consumer prices was approximately $£ 12.5$ billion. The last sum represented $36 \%$ of what the British consumer spends on food in retail establishments for home consumption.

\footnotetext{
* The detailed studies are published in the "Etudes et Dossiers" series No. 165, February 1992.
} 
Of the 7 billion meals per year (or approximately 19.5 mio. per operating day):

- $34 \%$ were served by institutional segments,

- $9 \%$ in office / factory cafeteria,

- $54 \%$ in commercial catering,

- $3 \%$ in transport catering.

The meal output is at best stable in the institutional field (schools, universities, hospitals, clinics, retirement homes, armed forces, etc.), slight growth in office / factory catering (both blue and white collar), steady ( $2 \%$ per year) growth in commercial catering and strong (4-5\%) growth in transport catering. The last includes airline and airport, motorway and highway, station and on train and ship catering.

The catering market is made up of some 35 sub-sectors which differ in ownership/jurisdiction, purpose (profit, not-for-profit), size (number of meals per day), clientele (captive, non-captive, age, etc.), meal budgets and meal prices, catering system (fresh, cook-chill, cook-freeze, etc.).

There are three major contract caterers (Gardner Merchant, Compass, Sutcliffe) in the UK and contract caterers as a whole served $40 \%$ of all meals in the office/factory area. They are starting to increase their penetration in the state school and state hospital area with the stimulus of compulsory competitive tendering (CCT).

The UK has many large restaurant chains and chains had a penetration of $17 \%$ in 1989 (meals served) in the commercial catering area, with future further growth. There are about 55,000 pubs in the UK and 25,000 of these are owned by the major brewers. Catering in pubs has very great potential.

\subsection{The 1990 food safety act}

This Act came into force in April 1991, in response to a growth in the number of cases of food poisoning originating through pathogenic agents in food (listeria, salmonella, etc.), particularly from poultry and eggs, and from faulty food hygiene in meal preparation. Food poisoning occurs both in the home and from the use of catering establishments with the latter accounting for about two-thirds.

There has been a rapid growth in declared cases of food poisoning, rising from 10,318 in 1980 to 38,086 in 1989 . Salmonella, in the period $1986-1988$, was responsible for $92 \%$ of cases and for 145 (97\%) out of the 150 deaths due to food intoxication in the same period.

The Act had specific bearing on the catering sector although it also covers food manufacture and food retailing. The Act deals with the whole chain from food procurement, temperature conditions for storage, through meal preparation and cooking, re-heating and serving of meals.

The main offences of the caterer are:

- buying food for sale which he knows to be sub-standard, contaminated or beyond "consume-by" dates,

- not respecting temperature constraints for chilled foods or for keeping food hot,

- rendering food injurious to health or which does not comply with food safety requirements,

- selling food which is not of the nature, substance or quality demanded,

- falsely or misleadingly describing or presenting food. 
Rendering food injurious to health is one of the most serious offences and the act is committed whether done deliberately or unknowlingly. Other offences include:

- failing to register premises,

- not giving adequate basic food hygiene training,

- obstructing enforcement officers,

- failing to comply with improvement notices or contravening prohibition orders.

Fines have been drastically increased (from $£ 2,000$ to $£ 20,000$ per major offence) and prison sentences are possible for serious offenders.

The Act is enforced via the various borough/district authorities of the UK, using the some 7,000 EHO (Environmental Health Officers) who are deployed in the UK. These have powers of entry without notice, inspection, taking and analysis of samples, and local magistrate court support for improvement or closure. There was strong evidence in the survey that these powers are being vigorously used.

The caterer's defence is that he has proven the exercise of "due diligence" by the following measures :

- hygiene training for all relevant staff,

- purchasing: inspection of suppliers' premises and checks on deliveries (quality and temperature),

- modernity and maintenance of chilled and frozen storage facilities,

- efficient clean preparation surfaces and cooking equipment,

- evidence of system in catering hygiene systems.

\subsection{Consumer litigation}

Most consumers only take action in complaints of food poisoning if they are sure of the origin (several people involved in the same catering establishment or event so that the "finger can be pointed") and if there is gravity (hospitalisation or medical intervention). From US evidence, probably only 1 in 100 cases of food poisoning is actually declared.

One of the preoccupations of the caterer is that the consumer will resort more to legal claims for damages suffered when frequenting a catering establishment.

Food poisoning is the "calamity" of the food service operator but the main customer claims are related to slips and falls (e.g., in the car park), foreign matter in the food (tooth damage), and spillage errors in service (food on clothes).

The Courts and Legal Services Act 1990 Section 1958 has enabling provisions whereby solicitors can act for plaintiffs in claims with the fee contingent on success.

However, the UK magistrates court system is more balanced than the US jury system and the excesses of the US system are not expected.

There is evidence however that consumers are aware that they can achieve high levels of legal expenses cover for a small outlay, solicitors are encouraged to be more commercial and trade unions will try to hold on to membership by the offer of free legal services.

The British consumer is likely to be more litigious.

\subsection{Case histories of large catering groups}

Six large catering groups were profiled through key interviews to illustrate operations, risk management and control systems and insurance practice. 


\subsubsection{Forte PLC}

Size

Turnover $£ 2.47$ bio (1990), 100,000 employees, largest hotel/catering group in the UK.

Activities

- Wide variety of restaurant chains ranging from fast food (KFC) through highway, steak, seafood chains,

- airport and in-flight catering (leader in the UK),

- contract catering (Gardner Merchant), the largest in the UK,

- central production units (particularly Puritan Maid),

- hotel chains (e.g., Crest).

Procurement

Nominated suppliers with inspection of premises, with a lot of supplies taken from inhouse Puritan Maid.

\section{Hygiene}

Group Food Technology unit, inspection visits to all units, samples regularly tested of meals prepared. Great emphasis on complete systems.

\section{Management}

Separate line management for major activities. Staff functions such as legal and insurance are centralised.

\section{Insurance arrangements}

Have had captive for 13 years on grounds of cost and complexity of business. Insurance covers fire, liability (public and employee), automobile. There are layers of cover, with Royal providing global cover on top of the captive insurance. Minet is used as brokers worldwide. For employees, the main claims are slips and falls followed by cuts, scalds and burns. Claims have grown slower than turnover and number of employees. For public liability, the claims concern customer accidents and waiter errors, foreign body in food with food poisoning well behind. Premiums as a percentage of turnover have declined and little change is expected.

\subsubsection{Bass $P L C$}

Size

Turnover : $£ 5.14$ bio (1990), owns Holidays Inns, about 6,500 pubs and has $23 \%$ of the UK beer market.

Activities

- Hotels (essentially Holiday Inns with 320,000 rooms),

- pubs (both managed and tenanted),

- brewing

- soft drinks/off licences,

- leisure (mainly betting).

The main restaurant formula is Toby Carvery and Toby Grill Rooms.

For Holiday Inns, the Europe, Middle East and Africa are run out of Brussels with the US HQ handling the rest. 


\section{Procurement}

A central purchasing department nominates suppliers and in $90 \%$ of cases, units purchase direct from these suppliers. Most meat and seafood items are bought frozen. Suppliers' premises are inspected.

Hygiene

They have their own hygiene audit unit which together with an outside company inspects supplier premises and their own catering premises.

\section{Management}

There are separate management structures for the main divisions.

\section{Insurance arrangements}

BASS has had a captive insurance company since 1972, established due to frustrations with the UK insurance market. The Group Insurance Department has a staff of 22 . Very little use is made of brokers. They have a global $\$ 325$ million cover for public and product liability. Premiums are allocated internally to reflect claims costs. Captive insurance companies are located in Gibraltar, Bermuda and USA. With regard to Holiday Inn franchisees, there is full indemnity provision for BASS and standards are laid down. A $\$ 10$ mio insurance facility is available on a facultative basis for franchisees but they can make their own arrangements. In the employee liability area, a major concern is violence in pubs and personal acccident cover has been arranged for three times the annual salary.

There is awareness of a growing litigation trend which is increasing the employers' and public liability risks. The future direction of the insurance arrangements is under review.

\subsubsection{Whitbread PLC}

Size

Turnover: $£ 2.06$ bio (1990): retailing sales (from restaurants, managed pubs, hotels and off-licences) are more than $50 \%$ of total sales.

\section{Activities}

- Originally a brewer with major development of restaurant chains including steak chains such as Beefeater, Churrasco, Denver, joint venture with Pizza Hut and theme restaurant TGIF,

- owns some 5,600 pubs of which 1,600 are managed by Whitbread employees,

- three hotel concepts (about 80 hotels).

\section{Procurement}

There are separate purchasing arrangements for, on the one hand, the restaurant chains and hotels and, on the other hand, the managed pubs. For the latter, purchasing agreements are negotiated centrally and the individual units order direct from distributors. All meat is bought fresh. For the restaurants, the major chains establish their specifications, nominate suppliers and negotiate prices. Products are distributed through third party distribution companies.

\section{Hygiene}

Suppliers' premises are inspected before contracts are established by in-house Whitbread staff. There are also checks on products on delivery. Centralised hygiene control staff make regular visits to Whitbread's restaurants and pubs. 


\section{Management}

There is a separate management structure for each division with the managing directors of each division present in the Executive Committee.

\section{Insurance arrangements}

Whitbread created a captive insurance company in 1986 on the grounds of the complexity of the business and to stabilise costs. The in-house insurance department has a staff of 15 . They recently made a change of broker to WILLIS CORROON. For employee claims, the main ones are slips and falls, burns, scalds and cuts, followed by injuries to bar staff through fighting.

For the brewery side, with the large plants, first priority has been put on catastrophe risk (e.g., through massive contamination of brewing plant). In pub catering and restaurants, the main public liability claims are, in order of importance, slips and falls, spillages on customers, foreign bodies in food and food poisoning.

Little change is expected in insurance arrangements as they are satisfied with the current level and quality of cover. Cost increases have been in line with inflation but less than the growth in turnover, employees and profitability.

\subsubsection{Sutcliffe services group}

Size

Part of P\&O Group (turnover £ 4.59 bio) with turnover of about $£ 1.19$ bio (1990). Sutcliffe Catering inside the services group is the third largest contract caterer in the UK with about 2,000 contracts and 17,000 employees.

\section{Activities}

There are no hotels or commercial restaurants implying investment. Catering is contract catering in a wide variety of employment, health care, leisure and educational facilities.

\section{Procurement}

There is central negotiation of contracts but purchase and control on quality of products (due diligence) is the responsibility of individual units. Strict temperature controls are made for red meat, poultry and seafood purchases. Regular visits to suppliers are made by the in-house Environmental Health Department.

Hygiene

A food hygiene training course is run for all the 17,000 catering staff. The Environmental Health Department visits all Sutcliffe operated client facilities on a regular basis. Samples of all protein dishes prepared are kept for 48 hours.

\section{Management}

The catering group is organised on a regional basis in the UK with a managing director. The chairman of the Service Group reports direct to the P\&O Group Managing Director.

\section{Insurance arrangements}

Insurance is managed by the company secretary. The broker Sedgwick is used for handling and placing insurance for employee and public liability. The main employee accidents are slips and falls, and cuts and burns. A broker is used for rapid response and economy in the handling of claims. Premiums are payroll related and reflect the accident/ 
liability record of the previous year. Premiums as a percentage of turnover are now lower than 1980. The main public claims relate to accidents, foreign matter in food and, insignificant, food poisoning cases.

Little change is expected in the insurance arrangements.

\subsubsection{Compass group}

Size

Turnover: £ 258 mio, 19,000 employees, 100 million meals per year, previous Grand Metropolitan, then management buy-out.

Activities

$87 \%$ is in contract catering, mainly in offices/factories and $13 \%$ in hospital management. There is management of commercial restaurants but no investment.

\section{Procurement}

Suppliers are nominated under contract with call off by individual units. There is regular inspection of suppliers' premises and unit managers are responsible for checking products as they arrive at the units.

\section{Hygiene}

The in-house Technical Quality Control Department, apart from inspecting supplier premises, also inspects the units (about 3,300) where Compass has the catering contract. All staff are given hygiene training in conjunction with the Institute of Environmental Health Officers. A sample of every meal cooked is kept for 3-4 days in case quality evidence is required. The hygiene manager claims that in the last three years, there has been no insurance claims either for food poisoning or presence of foreign bodies caused by their own staff's cooking.

\section{Management}

The company is organised on a regional basis. Overall, there is a Chief Executive and three executive directors.

\section{Insurance arrangements}

The company secretary manages insurance matters and they work through brokers, normally two which are being reduced to one. This keeps down internal costs. Employee liability cover has been increased from $£ 2$ million to $£ 10$ million. The main claims are slips and falls, cuts, burns, scalds and skin/dermatitis. Claims range from $£ 40$ up to $£ 50,000$.

Public and product liability indemnity level has been increased from $£ 10$ mio to $£ 20$ mio partly due to inflation but also in anticipation of a more rigorous enforcement of the Food Safety Act. The main claims related to customer falls, foreign body in food and food poisoning. In anticipation of increasing consumer litigation, they may take out insurance cover for legal costs.

\subsubsection{Albert Abela}

Size

Turnover not disclosed (privately owned from Monaco). 22,000 employees, operating in 33 countries, serving more than 300,000 meals/days.

Activities

This is very varied: 
- site camp operation, for fixed and non-fixed facilities in Middle East, Africa and Latin America,

- airport and airline catering (50,000 meals/day to more than 65 airlines and in 9 international airports),

- hospital and nursing home services (50,000 meals/day to over 100 hospitals),

- school/university catering, mainly in France where a central production unit with 20,000 meals/day is based in Nice,

- office/industry catering, again mainly France,

- hotel and restaurant management in France, Middle East, Brazil and Jamaica.

The spread of activities by type and geographical area is fairly unique and operating with virtually no infrastructure available in Africa is a major uncertainty.

\section{Procurement}

The Management Services Department sets purchasing policy guidelines and draws up recommended lists of suppliers. Actual purchasing is made by units in view of the decentralisation of operations.

Hygiene

Guidelines and consultancy are provided by the Management Services Department but quality control and hygiene procedures are the responsibility of the operating management.

\section{Management}

Overall control and coordination is made from Monaco, with a high degree of operating decentralisation. Abela Management Services in London provides technical support for recruitment, training, purchasing and insurance.

\section{Insurance arrangements}

Abela Management Services develop coherent overall strategy lines. Overall umbrella coverage for product and public liability is arranged from London with the limit recently increased from $£ 20$ mio to $£ 30$ mio. Country operators make their own arrangements inside strategy lines. Higher liability cover is arranged for the USA market. They work with a variety of large and small brokers. Little change is expected in the future with regard to insurance arrangements.

\subsection{Review of catering practice in selected sectors}

A screening was made of several catering sub-sectors to establish procedures and operations and response to the Food Safety Act.

\subsubsection{State hospitals}

\section{Structure}

There are 2,470 state hospitals in the UK, compared with 2,607 independent hospitals. $90 \%$ of hospital beds are in the state sector due to the much larger average number of beds. About 580 million meals/year are served in state hospitals.

Hospitals are under the overall jurisdiction of the Department of Health but administered by Regional Health Authorities. These, under government pressure, have become purchasers of services from individual hospitals. Hospitals have gained more independence and responsibility, encouraged to take Trust status, and have been obliged to put out to 
competitive tendering catering, cleaning and laundry services. Some of these contracts have been placed outside with commercial operators but in catering most contracts were won by inside catering departments.

\section{Catering systems}

There are several complexities in hospital catering:

- 365 day operation, including weekends, supplying three meals per day tends to create monotony and apathy among the catering staff,

- staff are there all the time and most hospital patients are short duration so that menu cycles must avoid menu fatigue for the staff,

- there is quite a high percentage of dietetic meals for hospital patients,

- the problem of keeping food hot when it leaves the main kitchen and is transported to the wards. Cooled food is poor tasting and slowly cooled food is the most potent for the proliferation of bacteria. Several systems are used :

- food is distributed to the wards chilled and is reheated in the ward, either in regeneration ovens or heating trolleys at a time to suit the ward sister,

- hot line plated meals in the kitchen: however there is a trend to transport in bulk to the wards and plate at the ward site as the food keeps hotter,

- catering departments lose control as trolleys leave the kitchens and this is the weakest part of the hospital catering chain.

\section{Procurement and quality control}

Purchasing is made by the catering manager of each hospital but within a remit of contracts and suppliers negotiated by the regional contracts officer. Suppliers' premises are inspected before the initial award of a contract and thereafter the frequency varies. Products are inspected on arrival by catering advisors and representatives from the hospital district supply centre which placed the original contract.

Regular training is given on hygiene and on the implications of 'due diligence'. There is quality control sampling of products, trend to smaller stock-holding and meal samples are retained for four or seven days.

\section{Insurance}

Insurance cover is normally placed by the legal departments at regional level for employee and public liability. If a catering contract is won by an outside contract caterer, the latter has to take the insurance cover for employee and public liability. There is a trend to delegate insurance decisions to individual hospitals to encourage risk management 'where the action is'. As catering departments in hospitals also cater for outside functions, they take out insurance here for ten times the value of the function to indemnify themselves against injury or food poisoning.

As state hospitals can no longer claim crown immunity, there is growing awareness of the need for extreme care in catering and that the consumer is increasingly conscious of his rights. 


\subsubsection{State schools and other local authority catering}

\subsubsection{State schools}

\section{Structure}

There are approximately 24,500 primary schools and 4,300 secondary schools in the UK. About 4.4 million meals per day are served during terms (190 days per year), or about 840 million per year.

The schools are controlled at district authority level - county or borough.

The British school meal has long had a nutritional purpose but:

- nutritional guidelines stopped in 1980,

- there is no longer an obligation to produce a full hot meal service and several counties have opted out,

- compulsory competitive tender has brought in some commercial contract caterers,

- there is still a statutory obligation to provide free meals for children of families on income support.

\section{Catering systems}

The previous system was fresh cooking of a typical "meat and two veg plus pudding" meal. Primary schools still tend to have this set menu or a tray meal system with a set price whereas secondary schools are usually cash self-service cafeteria. There is a tendancy to give the secondary school children what they want, hence the increase in hamburgers and chips.

The kitchens are usually well equipped with stainless steel work surfaces and there has been considerable expenditure on storage equipment. There is much less stress than in hospital kitchens - only one meal a day in term time. As the customers are children, there has been considerable degree of care and virtually no cases of serious food poisonig.

Procurement and quality control

The catering system is controlled by the catering officer in each council or borough. Procurement is organised by the supplies department in the local authority and some county councils have pooled buying to get more volume. Specific suppliers are selected after inspection of premises and chosen for each product area (dairy, frozen foods, etc.). Contracts range from 1-4 years and premises of suppliers are usually inspected during the contract. Checks on deliveries are made on a rotation basis with regular checks for quality and temperature limits. With regard to staff training, all school catering is run by managers qualified to degree level and all staff go through health and hygiene training. The Local Authority Caterers Association offers training courses and seminars.

\section{Insurance}

County councils tend to group insurance for different departments and catering employees come under employee liability. The other main item is public liability and official indemnity if someone is caused financial loss. Some carry their own risk re equipment as they feel that the premium outweight the cost of replacement.

The report shows the actual systems used in three county councils:

\section{Essex}

The catering contract in CCT was won by the in-house catering team. 


\section{Wiltshire}

Set up its own Concept Catering semi-autonomous unit which won the catering contract. This body had to make its own insurance arrangements for public and employee liability.

\section{Northamptonshire}

This county opted out of providing school meals, saving £ 2.5 mio per year. It now provides only a sandwich packed lunch for those children qualifying for free school meals. The remaining schools are now fed by 60 lincensees from four catering companies and selfhelp groups. The licensees are given the right to use the kitchen premises but on the understanding that they will have to upgrade the kitchen facilities. Licencees have to take out their own insurance cover.

\subsubsection{Meals on wheels}

\section{Structure}

The provision of meals to the homes of the infirm elderly is an obligation on local authorities. The production of meals was put out to competitive tender but distribution is still wholly or partly charitable. In 1990 it is estimated that about 170,000 meals/day were produced and delivered or about 41 million meals per year. Charges per meal vary with income levels. There is discretion among the elderly about type of meal and time of delivery.

\section{Catering systems}

Meals can be prepared by in-house authority catering teams, by outside contract caterers, use of bought in frozen meals, home helps cooking in the house of the pensioner, neighbours providing/cooking as hot meal and delivering it.

Meals are distributed by paid staff using the vans of the local authority, volunteers using the same vans, or volunteers using their own transport.

\section{Procurement and control}

Purchasing is made by the local authority supplies department if an inside service. If the catering contract has been sub-contracted, the local authority monitoring officer checks on the performance of all catering contracts.

Two examples are given for London boroughs as to how the service works. These confirmed the range of meal preparation possibilities and distribution alternatives. Insurance is made via the local authority and the only claims problem seems to be people slipping when delivering meals.

\subsubsection{Event catering}

This is an under-researched area of the British catering market, involving hundreds if not thousands of operators, mainly small, involved in catering for sports events (such as Wimbledon), weddings, exhibitions in both fixed and temporary facilities. Meals can be prepared in advance and delivered to the event location with problems of temperature respect (keeping hot and chilling) or prepared on site as in the major exhibition events such as the Farnborough Air Show.

Apart from the registered companies, there are a lot of "private" initiatives with an overlap between private and public (individuals undertaking to cater for a friend's wedding party on a paid basis). 


\section{Structure}

The Mobile and Outside Caterers Association was set up three years ago and has about 350 members, mainly small. Large groups such as Ring \& Brymer and Letheby \& Christopher are not yet members. The Association is involved in drawing up standards for its members concerning hygiene and insurance.

\section{Catering systems}

This can range from hot and cold drinks and sandwiches for the local cricket team to the most elaborate hot and cold buffet in entertainment marquees at prestigious sporting events. The distance and time which can separate cooking from eating makes event catering particularly liable to cases of food poisoning if there is not rigorous respect for keeping hot food hot (above $65^{\circ} \mathrm{C}$ ) or keeping chilled food which is on offer for more than four hours.

\section{Control and insurance}

The large caterers contacted are rigorously following the provisions of the Food Safety Act (inspection of suppliers' facilities, temperature control in distribution, hygiene training, increase of chilled storage facilities, etc.).

The Mobile and Outside Caterers Association has taken a number of initiatives:

- every member must have third party product and public liability insurance,

- members are being encouraged to obtain their hygiene certificate (event organisers now often insist on it),

- a national inspection service is being set up which will be independently run and will check members' premises and standards at least once a year,

- members will be required to show their insurance cover to the Association to ensure that it is adequate,

- making members aware that they must conform to the Food Safety Act provisions or go out of business.

The small event caterers are doing their best with limited resources as far as equipment investment is required and little power on their food suppliers. They take their hygiene and food handling exams and are being obliged to show responsibility in insurance cover.

The policing of the environment health officers will also be more severe and a further precaution against food intoxication.

\section{The catering market in France}

\subsection{General overview}

A total of more than 5 billion meals per year is served outside the home in France. These are served by some 219,000 establishments of which:

- 127,000 are commercial (restaurants, cafes, hotels, etc.),

- 92,000 are institutional (schools, hospitals, homes, company cafeteria, etc.).

Approximately $60 \%$ of the total meals are served by the institutional sectors and $40 \%$ by the commercial but the growth of the latter is faster than the institutional. In value terms, the commercial catering meals represent $60 \%$ of the total output value of approximately FF 190 billion in 1990 and the institutional $40 \%$. 
The major forces for change are the restaurant chains in the commercial catering market and the profit making contract caterers which mainly operate the cafeteria in the office/factory catering market and increasingly in schools and hospitals. Restaurant chains have already a $23 \%$ penetration in value of the commercial catering market and this will probably increase to $31 \%$ by the year 2000 . Contract caterers have about a $20 \%$ penetration of institutional sectors in 1990 and this will probably increase to $23 \%$ in 2000 .

\subsection{Fiscal and regulatory aspects}

Fiscal

In the institutional sectors, where the catering is managed in-house, there is no VAT (value added tax).

When the catering is given out to a contract caterer, the rate is $5.5 \%$. In commercial catering, the VAT rate is $18.6 \%$ except for take-aways where the rate is reduced to $5.5 \%$.

\section{Regulatory}

France has been in the vanguard of enactments concerning food hygiene and public health. Key decrees are 21.7.83 which modernised the general law of 1905, with particular reference to food quality and the rules governing places preparing food. Public health provisions at the departmental level are derived from the 1983 decree. Food hygiene is covered at three levels: products which can be added to food, maximum limits on chemical or microbial residues and good food hygiene practice. Major emphasis is put on:

- the quality of raw materials,

- campaigns against food contamination (place, equipment, personnel, etc.),

- control on the development of contaminating micro-organisms through strict temperature control.

However, the commercial catering sector did not take up the possibility of applying for the "guarantee of safety" which had been used for central kitchens.

\subsection{Basic conduct rules for catering kitchen organisation}

The objective of institutional catering can be defined as serving meals at a fixed time, once or several times a day, to an important number of customers, at determined temperatures, irreprochable taste and bacteriological quality, whose presentation should be agreable, distribution easy and in conditions of economic operation compatible with good management practice. As tasks in the catering kitchen are varied (some requiring handling of dirty products such as kitchen waste, others impeccable handling of food products), it is vital to have a physical separation of the "clean" and the "dirty" and these circuits should never cross. The circuits are:

- food entry (clean),

- waste from meal preparation (dirty),

- clean dishes (clean),

- dirty dishes (dirty).

Guidance is given on environment, exposure to sunlight, height (storeys), shape.

\subsection{Size of kitchens (number of meals)}

In 1989 , a census was made by the DGAL of 53,749 catering establishments operating in the institutional area (schools, hospitals, prisons, office/factory cafeteria). In terms of numbers of meals served per day: 


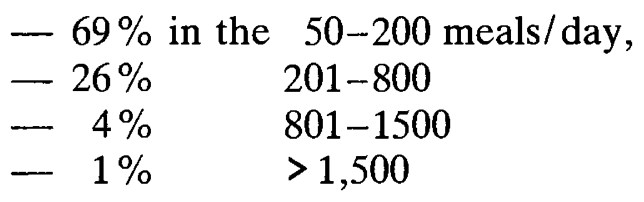

There has been an increase in the number of 50-200 meals/day, reflecting a more human dimension for institutional catering.

\subsection{Hygiene situation of central kitchens in France}

France has been a leader in centralised meal preparation systems, particularly for refrigerated systems. Some of these are very large and can serve up to 20,000 meals/day. The decree of 26th June 1974 set out the conditions for obtaining the "marque de salubrité" (hygiene gold seal) with respect for the preparation, preservation, distribution and sale of preprepared meals.

The analysis by the DGAL in 1990 showed 4,941 central kitchens in operation in 1989 of which $3,783(77 \%)$ in hot /fresh delivery, $1,127(22 \%)$ in chilled and $31(1 \%)$ in frozen. In the same year, 3,735 (76\%) had obtained the „marque de salubrité”.

In France, hygiene control on pre-prepared meals is with the state authorities but it should be displaced to self-policing by the operators in line with the EEC norms.

\subsection{Different catering systems for central kitchens}

The trend is away from hot/fresh delivery systems which require daily preparation and delivery towards refrigerated systems which give storage possibilities up to six days (21 days for exemplary sous-vide). This makes it possible to eliminate weekend meal preparation for hospitals and meals can be prepared in one shift. However, great hygiene care is needed in meal preparation and there is additional investment in rapid chilling cabinets and in refrigerator storage equipment to keep the meals at $+3^{\circ}$ centigrade. Meals have also to be reheated from $+3^{\circ}$ centigrade to $+65 \mathrm{C}$ in less than one hour. Frozen systems are little used, as they require heavy investment for freezing. Freezing also limits the range of meals.

However, each central kitchen is a special case and should be the object of a study of clientele, location and distribution frequencies.

\subsection{New techniques of preservation and cooking \\ Preservation}

New preservation systems (following on from sterilisation, dehydration, freezing, etc.) have made their appearance and give increased security to the food supply to the caterer.

Controlled atmosphere packaging

Use of inert gases (normally $\mathrm{N}^{2}$ and $\mathrm{CO}^{2}$ ) inside the packaged product to retard degradation: used for meat, fish, fruit and vegetables.

Vacuum packaging

A vacuum is drawn inside impermeable film packaging. Hygiene and the cold chain must be respected. The technique is very suitable for meat and particularly beef.

\section{Ionisation (Irradiation)}

Low level short duration dose of irradiation which does not change the physical structure of foods. Used for fruit and vegetables (drives away parasites, destroys bacteria, stops germination...) and meat and animal origin products (destroys pathogenic germs and prolongs shelf life). 


\section{Freeze-Drying (Lyophilisation)}

Very fast deep freezing, followed by dehydration in a vacuum: used for coffee, mushrooms, soups.

\section{Aseptic Filling}

Use of sterile medium to avoid any bacteriological contamination, particularly for dairy and processed meat products.

\section{Cooking}

\section{Under Vacuum Cooking}

The food product is placed in the plastic packaging material, a vacuum is drawn and the product is cooked at a constant temperature in its own juice at between 60 and $90^{\circ} \mathrm{C}$. A good quality high hygiene product results with shelf life at $2^{\circ} \mathrm{C}$ up to 21 days.

\section{Extrusion Cooking}

Used for biscuits and snacks, raw material is compressed and cooked at the same time. After cooking, the product decompresses and takes on an expanded texture.

\section{Microwave Cookery}

Use of equipment generating an electromagnetic field which causes a movement of the water molecules in food and so producing heat. Used for the rapid thawing of products or for accelerated cooking combined with other methods of cooking.

These technologies provide an increasing range of carefully tailored food products for the caterer (who increasingly practices an "assembly kitchen") and remove a lot of the tedious, low skilled and dangerous activities in the kitchen.

\subsection{The risks of food poisoning and food hygiene}

A group case of food poisoning is declared when at least two cases with the same type of symptoms (normally gastro-intestinal) are discovered which can be linked to the same food origin. Foods can be passive or active in the transmission or multiplication of infectious pathogenic agents. Aggravating factors are:

- long interval between cooking and consumption,

- temperature,

- presence of oxygen,

- poor control of purchases,

- long interval between purchase of foods and cooking,

- defective storage.

The whole food chain has to be controlled.

The total number of "sources" (foyers) of food poisoning grew up to 1989 but declined in 1990.

$\begin{array}{lrrr}\text { YEAR } & 1988 & 1989 & 1990 \\ \text { "Foyers" } & 309 & 610 & 593 \\ \text { No. of sick } & 6,331 & 11,146 & 9,017\end{array}$


Various forms of salmonella constituted the most important form of food poisoning and have increased to over $50 \%$.

$\begin{array}{lccc}\text { \% Salmonella } & 1988 & 1989 & 1990 \\ \text { in total } & 35.4 & 51.2 & 51.7\end{array}$

It is believed that there is a strong under-declaration of cases of food poisoning.

The percentage of patients with food poisoning who had to be sent to hospital was $10 \%$ in 1988 and had dropped to $7 \%$ in 1989 even though the number of reported cases had increased on 1988 .

There were two deaths in 1988 and 23 deaths in 1989, all from salmonella. Of the food products which are at the origin of food poisoning, eggs and egg-derived products are the most important for salmonella and in 1989 first in overall importance. Red meat and poultry are second followed by seafood. Milk and dairy products have been relatively unimportant.

About two-thirds of cases of food poisoning occur in different sectors of the catering market with about $25 \%$ (mainly salmonella) in domestic househoulds.

With regard to the causes (factors contributing to the food poisoning), non-respect for the cold chain was a contributing factor in $58 \%$ of cases, error in preparation/cooking $(58 \%)$ and too long delay between cooking and eating $(47 \%)$. As the whole food chain is involved, most cases of food poisoning are caused by two or more errors in the chain.

\section{Treatment/Remedy}

Apart from changing the defects in the catering chain, training of staff is one of the most important measures of permanent protection.

It should also be obligatory for caterers to keep in cold storage samples of all meals prepared for three days.

While attempts are being made to develop bacteria resistant to strains of salmonella or listeria, these are some years away and the best precaution is careful respect for the whole food chain.

\subsection{Services responsible for hygiene control}

There are three key bodies:

- the DDCCRF (consumption, competition, fraud) is responsible for policing the quality of all non-meat food products at the level of the food processing industry and wholesale and retailing,

- the DSV (veterinary services) looks after meat-based food products and with the

- DDASS (health and social aspects), are both responsible for the control and inspection of catering premises. The DSV has a laboratory in each department to carry out the micro-biological analyses of food products.

\subsection{Procedures in the event of food poisoning}

Food poisoning is the major and permanent risk of the catering industry and entails compulsory declaration to the DDASS of the department concerned. The inspection service carries out : 
- an epidemiological study.

- a microbiological analysis of the suspect food product,

- a control on methods/conditions of meal preparation if the poisoning has taken place in a catering establishment,

- the implementation of remedial measures.

The inspectors have powers to close down offending premises on a temporary or permanent basis.

The most important aspect for minimising cases of food poisoning is proper hygiene training for all personnel.

\subsection{Employment in the catering market and the risks}

The total number of persons active in the catering sector was 762,000 in 1989 . Of these, $251,000(32.9 \%)$ are non-salaried. The rate used to be higher ( $46.5 \%$ in 1980$)$ but is now in decline with the increased role of chains and a more professional organisation throughout the catering market. It is in the bar area that the proportion of non-salaried staff is the highest $(69 \%)$. The work force has a high content of young ( $20 \%$ with less than 24 years), a lot of foreign workers (16\%) and a growing proportion of women : these are a minority in the commercial catering area (unstable and long hours) and a majority in the institutional catering field.

With regard to the length of the working week, this is 39 hours per week in the institutional area, with catering establishment serving mainly a midday meal. In the commercial catering area, with long opening hours, the weekly duration of work is 43 hours for kitchen staff, 45 hours for other salaried staff and 52 hours for night shift staff (hall porter, etc.). These hours are often not respected and the long hours worked in the catering industry certainly cause fatigue and a loss of concentration. Neither is good for employee safety or for respect of food hygiene norms.

\subsection{Work-place accidents in the catering industry}

The accidents in the catering industry in France are broken down between the commercial catering and institutional catering fields. Published statistics concerning accidents show the following:

\begin{tabular}{cr}
\multicolumn{2}{c}{ Commercial } \\
1985 & 1989
\end{tabular}

No. of employees (A)

No. of accidents with stop of work (B)

$\% \mathrm{~B}$ of $\mathrm{A}$

No. of accidents with permanent incapacity

No. of deaths

Days lost per temporary

incapacity / 1000 employees
$173,135218,686$

$11,011 \quad 12,933$

6.36

5.91

678

639

4

3

1,574

1,606

1,919

1,526 
It can be seen that the number of accidents as a percentage of total employees is in sharp decline in the institutional area and has now come below that of commercial catering. The mortality rate is very low. The number of accidents with permanent incapacity is in absolute decline.

With regard to the major causes of accidents, the most common are slips and falls, accounting for about $35 \%$. Saws and knives account for a further $18-19 \%$. Cuts and burns at $35-40 \%$ are still the most common type of injury. Between 43 and $45 \%$ of injuries are to the hand.

Accidents rates should decline as vegetables and meat are increasingly bought in prepared form and there is research to find hygienic but non-slip floors.

\subsection{Case histories of contract caterers}

The three largest contract caterers in France were interviewed and profiled to establish their operations, quality control systems, insurance policy and trends.

\section{Générale de restauration}

Created 1966

Ownership:

Management 35\%, ACCOR 30\%, CIE. GENERALE DES EAUX $30 \%$, others $5 \%$

Turnover (1990):

FF 2.9 billion

No. meals/year:

159 million split education $31 \%$, office/factory $42 \%$, health $26 \%$, other $1 \%$.

No. meals/day: $\quad 700,000$

No. of restaurants/cafeteria: $\quad 1,268$

No. of employees :

9,400 (25\% part time)

Organisation :

Paris - three divisions

Provinces - 22 regional managers operating as profit centres.

Central kitchens: GR operates 110 central kitchens and the operation in Lyon claims to be the most modern in Europe, serving 12,000 meals/day. With high hygiene control of sousvide systems, it achieves a 20 -day shelf life. GR, in partnership with Générale des Eaux, pioneered in the establishment of central kitchens.

Purchasing and Inspection: The chosen suppliers are referenced for call off by the units. Delivery to units is now made by suppliers. There is regular inspection of suppliers' premises (mainly large companies are used) and of their own cafeteria. A sample of all meals prepared is kept in cold storage for three days.

Training: The company has access to the Académie ACCOR for the training of its managers and its own AFHOR centre for training all new catering staff.

Insurance: The company mainly uses the broker Gras Savoye for its key insurance for public liability (FF 100 mio) and consequential loss (through closure of an operation) up to a maximum of FF 20 mio. 
Other brokers are used for :

- cover for the central kitchen operations,

- liability for potential erroneous advice given by their consultancy subsidiary,

- automobiles.

Consideration has been given to establishing a captive insurance company but this has not been done due to insufficient turnover.

\section{Eurest Collectives}

Created 1966

Ownership :

Turnover (1990):

No. meals/year:

No. meals/day:

No. restaurants/cafeteria:

Employees :

\section{Management, ACCOR group, SODEXHO}

FF 1.8 billion

103 million (1990) split education $26 \%$, office/factory $49 \%$, health $14 \%$, other $11 \%$

500,000

922

5,674

Organisation: There are 8 operational companies of which 6 who only carry out institutional catering. One company in the East of France only carries out office/factory catering. Fourteen regional managements, organised geographically or by economic sector, are the profit centres.

Central kitchens : Eurest operates central kitchens of which $95 \%$ are in chilled liaison.

Purchasing and inspection: Suppliers are referenced and units are provided with the list of suppliers' products and prices for direct call off. While retaining the right to inspect the premises of its suppliers, Eurest places a lot of emphasis on the partnership relationship with its food suppliers (Eurest was at one stage owned $50 \%$ by Nestlé).

Inspection of the cafeteria/restaurants is made by the official DSV (at departmental level), the internal committee of Eurest employees (CHSCT) by six private laboratories including the Institut Pasteur under contracts made by Eurest.

A sample of every meal is kept in cold storage for five days after preparation.

Training and Safety: The training budget was FF 13.5 mio in 1990 and up $43 \%$ compared with 1989 . This represents $2.73 \%$ of the salary bill. In $1990,1,521$ employees received training in hygiene and safety.

The total number of accidents has declined from 631 in 1988 to 584 in 1990 . The main causes of accidents are, in declining order of importance, slips and falls, cuts and burns and, far behind, food poisoning.

Insurance : Eurest uses one main broker SGCA and is insured with four insurance companies for employee and public liability, etc. Insurance cover is being modified to suit the requirements of a contract caterer: previously as member of the Wagons-Lit group, there was a heavy bias of catastrophe coverage. 


\section{SODEXHO FRANCE}

\section{Ownership:}

Turnover:

No. of meals/year:

No. of meals/day:

No of restaurants/cafeteria:

Employees:

\section{Pierre Bellon (founder)}

FF 2.8 billion (1990: France)

129 million, split education $27 \%$, office/factory $42 \%$, health $31 \%$ (SODEXHO is leader in the health area in France)

Central kitchens: SODEXHO has constructed about 10 central kitchens, built on a credit lease basis for local authorities who take title after 15 years. These are in chilled liaison.

Purchasing and Inspection: Chosen suppliers are referenced and submitted to the units for individual orders. Delivery is made by suppliers to units. The premises of suppliers are regularly inspected. A sample of all dishes served is kept in cold storage for one week in case of any food poisoning complaint. Apart from inspection from its own in-house services, SODEXHO uses ERCEM (a contract laboratory) for regular spot checks on the food in its cafeteria.

Training and Safety Record: Training services exist in each of the thre major divisons (office/factory, education, health). Some managers are trained in the Paris headquarters but the majority of staff are trained on the job. Accidents are on the decline, the most frequent being:

- slips and falls,

- cuts and burns.

Insurance: They use one broker - SOGEFI. There are three main policies :

- public liability for customers (FF 50 million) and unlimited employee liability,

- one multi-risk policy,

- one policy for covering computer system problems.

Individual insurances are taken out for major production units such as central kitchens.

Satisfaction is expressed with insurance arrangements.

\section{NOTA BENE}

The paper on "Quo Vadis? For General Insurance Industry in Developing Countries" by R. D. Samarth, published in the "Geneva Papers" No. 63/ April 1992 was prepared on the occasion of the Third World Insurance Congress held at New Delhi, but was not presented at the Conference as one of the official papers. 